\begin{tabular}{r|l|l|l}
$\begin{array}{c}\text { Case Reports in } \\
\text { Oncology }\end{array}$ & $\begin{array}{l}\text { Case Rep Oncol 2010;3:344-348 } \\
\text { DOl: 10.1159/000321262 }\end{array}$ & $\begin{array}{l}\text { Published online: } \\
\text { October 1, 2010 }\end{array}$ & $\begin{array}{l}\text { O 2010 S. Karger AG, Basel } \\
\text { ISSN 1662-6575 } \\
\text { www.karger.com/cro }\end{array}$ \\
\hline
\end{tabular}

\title{
Analysis of $\mathrm{pO}_{2}$ in Malignant Ascites of Patients with Peritoneal Dissemination of Gastric Cancer
}

\author{
Shigenobu Emoto Joji Kitayama Hironori Yamaguchi \\ Hironori Ishigami Shoichi Kaisaki Hirokazu Nagawa \\ Department of Surgery, Division of Surgical Oncology, The University of Tokyo, \\ Tokyo, Japan
}

\section{Key Words}

Malignant ascites $\cdot \mathrm{pO}_{2}$. Gastric cancer Peritoneal metastasis

\begin{abstract}
Objective: Oxygen is one of the most important environmental factors for tumor development. In this study, we examined $\mathrm{pO}_{2}$ in malignant ascites in patients with peritoneal carcinomatosis.
\end{abstract}

Methods: In 21 patients with peritoneal dissemination of gastric cancer, ascitic fluid was collected and its $\mathrm{pH}, \mathrm{pCO}_{2}$ and $\mathrm{pO}_{2}$ were determined using a blood gas analyzer.

Results: In 21 patients, $\mathrm{pH}$ of malignant ascites was significantly lower than that of arterial blood $(7.39 \pm 0.07,7.44 \pm 0.02, \mathrm{p}<0.05)$. Accordingly, $\mathrm{pCO}_{2}$ tended to be higher in ascites than in arterial blood. Unexpectedly, $\mathrm{pO}_{2}$ in malignant ascites showed relatively high values $(90.4 \pm 27.72 \mathrm{~mm} \mathrm{Hg}$ ), which were mostly the same as those of arterial blood $(97.09 \pm 10.33 \mathrm{~mm} \mathrm{Hg}, \mathrm{p}=0.858)$. Even in 19 patients whose samples were collected at bedside in room air, $\mathrm{pO}_{2}$ of malignant ascites was $85.94 \pm 23.94 \mathrm{~mm} \mathrm{Hg}$, which was patently higher than that in venous blood or in solid tumor tissues.

Conclusion: Since the oxygen level critically affects the sensitivity of tumor cells to chemotherapeutic agents through metabolic transformation, the oxygenic condition in the peritoneal cavity may be beneficial for the progression of peritoneal metastasis, and also clinically important in considering the efficacy of chemotherapy.

\section{Introduction}

Peritoneal metastasis with malignant ascites is the most life-threatening mode of metastasis and recurrence in patients with gastric [1] as well as ovarian cancer [2]. Peritoneal metastasis is considered to develop from carcinoma cells detached from the serosal surface of the primary site and dispersed in the peritoneal cavity. In general, the 
survival of seeded cells is largely dependent on the environment, in other words, the soil [3]. Oxygen supply is one of the most important environmental factors for cancer cell survival [4]. However, the oxygenic condition in the abdominal cavity is largely unknown. In this study, therefore, we collected ascitic fluid from patients with peritoneal dissemination of gastric cancer, and measured $\mathrm{pO}_{2}$ as well as $\mathrm{pCO}_{2}$ and $\mathrm{pH}$.

\section{Patients and Methods}

Twenty-one patients with peritoneal dissemination of gastric cancer who were admitted to the University of Tokyo Hospital, Japan, between March and June 2010, were included in this study. All patients had a considerable amount of ascites and had received systemic and/or intraperitoneal chemotherapy. In 19 patients, samples of ascites were collected through a drainage catheter inserted into the abdominal cavity, or through an access port system with the end of the catheter placed in the pelvic cavity and an access port system implanted in the subcutaneous space [5]. In 16 of the 19 patients, arterial blood was obtained by arterial puncture on the same day. In the other 2 cases, an insufficient amount of ascites was collected, and it was thus obtained just after laparotomy under general anesthesia. The samples were kept in a syringe with an airtight seal, and immediately analyzed with a blood gas analyzer, ABL800 (Radiometer, Copenhagen, Denmark). The results were statistically examined by paired Student's t test or simple regression analysis, and differences with $\mathrm{p}<0.05$ were considered to be significant.

\section{Results}

As shown in table 1, the $\mathrm{pH}$ of malignant ascites was $7.39 \pm 0.07$, which was slightly but significantly lower than the $\mathrm{pH}$ of arterial blood $(7.44 \pm 0.02, \mathrm{p}=0.033)$. Consistent with this, ascites showed a slightly higher $\mathrm{pCO}_{2}(43.70 \pm 5.5 \mathrm{~mm} \mathrm{Hg})$ than that of arterial blood ( $40.72 \pm 3.46 \mathrm{~mm} \mathrm{Hg}$ ), although the difference was not statistically significant ( $\mathrm{p}=$ 0.124). Interestingly, $\mathrm{pO}_{2}$ in malignant ascites showed considerably high levels (90.4 \pm $27.72 \mathrm{~mm} \mathrm{Hg})$, which were mostly the same as those of arterial blood $(97.09 \pm 10.33 \mathrm{~mm}$ $\mathrm{Hg}, \mathrm{p}=0.858$ ).

In patients 5 and 8 , in whom ascites was collected after laparotomy, $\mathrm{pO}_{2}$ was 151 and $133 \mathrm{~mm} \mathrm{Hg}$, respectively. Because they were controlled under general anesthesia, they were considered to be subjected to a higher percentage of $\mathrm{O}_{2}$ gas than that in room air. However, even in the other 19 patients, $\mathrm{pO}_{2}$ of ascites was $85.94 \pm 23.94 \mathrm{~mm} \mathrm{Hg}$, which was not significantly different from that of arterial blood, $97.19 \pm 10.40 \mathrm{~mm} \mathrm{Hg} \mathrm{(p} \mathrm{=}$ $0.149)$.

When $\mathrm{pO}_{2}$ in ascites and arterial blood was compared in 16 patients in whom ascites was obtained at bedside in room air, a positive trend was observed, although the correlation was not statistically significant (fig. 1).

\section{Discussion}

Our data have demonstrated that malignant ascites in gastric cancer patients showed an unexpectedly high oxygen tension, which was almost the same as that of arterial blood. $\mathrm{pO}_{2}$ was sensitive to the change of circumstances, and thus the procedure of sample acquisition and method of measurement are very important in assessment of the data. In our study, however, ascites was directly obtained through an intraperitoneal catheter or a 
subcutaneously placed port, kept in a syringe with an airtight seal, and immediately analyzed with a blood gas analyzer, just as for analysis of arterial blood. Therefore, it is unlikely that the relatively high $\mathrm{pO}_{2}$ values in malignant ascites are attributable to potential artifact during measurement.

A literature search showed little information on $\mathrm{PaO}_{2}$ in ascites. In 1977, Sheckman et al. [6] reported that the mean $\mathrm{pO}_{2}$ of ascitic fluid from 10 patients with liver cirrhosis was $43 \mathrm{~mm} \mathrm{Hg}$. Based on their data, they concluded that this $\mathrm{pO}_{2}$ was so high that anaerobic bacteria cannot survive in it and they are rarely the cause of spontaneous bacterial peritonitis. In 1982, Giltin et al. [7] also examined the ascitic fluid of patients with spontaneous bacterial peritonitis in alcoholic cirrhosis and showed that $\mathrm{pO}_{2}$ of their ascites was $50-82 \mathrm{~mm} \mathrm{Hg}$. Although the main aim of their study was to investigate the $\mathrm{pH}$ of ascitic fluid and they did not mention $\mathrm{pO}_{2}$ much, their data showed apparently lower values than ours. On the other hand, Simmen et al. [8] reported that $\mathrm{pO}_{2}$ of ascitic fluid with or without infection was $29(0-160)$ and $144(49-174) \mathrm{mm} \mathrm{Hg}$, respectively. This suggests that ascitic fluid may have a higher $\mathrm{pO}_{2}$ in some conditions, although the method and timing of sample collection varied greatly in their study.

More recently, however, Noh et al. [9] have reported that $\mathrm{pO}_{2}$ of ascitic fluid of patients with non-serosal invasive gastric cancer obtained during surgery was $136.49 \pm 0.66 \mathrm{~mm}$ $\mathrm{Hg}$. This value was considerably higher than that of cirrhotic ascites reported previously and is consistent with our results, or rather higher than our $\mathrm{pO}_{2}$ data. In their study, they collected ascitic fluid during abdominal surgery under general anesthesia. Since the anesthetic gas of operated patients is usually maintained at a relatively higher oxygen supply than that in room air, the high $\mathrm{pO}_{2}$ values were attributable to systemic hyperoxygenation. In fact, $\mathrm{pO}_{2}$ of ascites showed a positive trend with $\mathrm{pO}_{2}$ of arterial blood in our patients; and $\mathrm{pO}_{2}$ of ascites obtained during laparotomy in 2 cases showed the same $\mathrm{pO}_{2}$ values ( 151 and $133 \mathrm{~mm} \mathrm{Hg}$ ), which were similar to those in the study by Noh et al. Our data, together with those of Noh et al., suggest that $\mathrm{pO}_{2}$ in malignant ascites with peritoneal metastasis may be somehow elevated as compared with that in cirrhotic ascites.

Why is $\mathrm{pO}_{2}$ of malignant ascitic fluid so high? The efficiency of oxygen transfer through the peritoneum is considered to be elevated due to its rich vascular structure. Moreover, in peritoneal metastasis, vascular endothelial growth factor (VEGF) produced from tumor cells may further enhance the vascular permeability through tumor vessels [10]. The hyperpermeability condition may enable efficient oxygen delivery to peritoneal fluid via the microvessels lining the peritoneal cavity. In fact, the level of VEGF has been reported to be markedly high in malignant ascites $[11,12]$. The use of bevacizumab, a humanized monoclonal antibody to VEGF, may reduce $\mathrm{pO}_{2}$ as well as the volume of ascites.

In general, the oxygen tension in malignant tumor tissue is considerably decreased, and hypoxia is considered to be related to tumor progression and a poor outcome [1315]. A previous study to measure the oxygen partial pressure in tumors directly using an Eppendorf microelectrode demonstrated that $\mathrm{pO}_{2}$ in human solid tumors was less than 20 $\mathrm{mm} \mathrm{Hg}$ in most cases. This indicates that malignant ascites contained much more oxygen as compared with the primary tumor, and thus the high oxygen condition is thought to be a rather favorable condition for survival of disseminated tumor cells. This may be an important reason why so many tumor nodules can develop in the abdominal cavity. 


\begin{tabular}{r|l|l|l}
$\begin{array}{c}\text { Case Reports in } \\
\text { Oncology }\end{array}$ & $\begin{array}{l}\text { Case Rep Oncol 2010;3:344-348 } \\
\text { DOI: 10.1159/000321262 }\end{array}$ & $\begin{array}{l}\text { Published online: } \\
\text { October 1, 2010 }\end{array}$ & $\begin{array}{l}\text { O 2010 S. Karger AG, Basel } \\
\text { ISSN 1662-6575 } \\
\text { www.karger.com/cro }\end{array}$ \\
\hline
\end{tabular}

In summary, ascites of peritoneal metastasis of gastric cancer shows a notably high level of $\mathrm{pO}_{2}$. Various therapeutic approaches, including systemic chemotherapy, hyperthermia, immune therapy as well as aggressive surgery, have been attempted for peritonitis carcinomatosa. However, none of these has achieved a satisfactory clinical outcome. Recently, however, intraperitoneal chemotherapy has been shown to be effective for peritoneal metastasis in ovarian and gastric cancer $[5,16]$. Since the oxygen level critically affects the sensitivity of tumor cells to chemotherapeutic agents through metabolic transformation [17], the relatively high $\mathrm{pO}_{2}$ in malignant ascites is an important issue in considering the effectiveness of chemotherapy, especially intraperitoneal chemotherapy, for peritoneal metastasis.

\section{Acknowledgement}

This study was funded by the Ministry of Education, Culture, Sports, Science and Technology of Japan, and the Ministry of Health, Labor and Welfare of Japan.

Table 1. $\mathrm{pH}, \mathrm{pCO}_{2}$ and $\mathrm{pO}_{2}$ in ascites and arterial blood of the patients with peritoneal metastasis of gastric cancer

\begin{tabular}{|c|c|c|c|c|c|c|c|c|c|}
\hline \multirow[t]{2}{*}{ No. } & \multirow[t]{2}{*}{ Age } & \multirow[t]{2}{*}{ Sex } & \multirow[t]{2}{*}{ Method } & \multicolumn{3}{|l|}{ Ascites } & \multicolumn{3}{|c|}{ Arterial blood gas (room air) } \\
\hline & & & & $\mathrm{pH}$ & $\mathrm{pCO}_{2}$ & $\mathrm{pO}_{2}$ & $\mathrm{pH}$ & $\mathrm{PaCO}_{2}$ & $\mathrm{PaO}_{2}$ \\
\hline 1 & 28 & F & bedside & 7.317 & 45.3 & 108 & 7.405 & 46.6 & 100.2 \\
\hline 2 & 42 & F & bedside & 7.363 & 46.4 & 82.8 & 7.449 & 38.1 & 90.5 \\
\hline 3 & 49 & $\mathrm{~F}$ & bedside & 7.371 & 49.8 & 83.2 & 7.422 & 42.3 & 85 \\
\hline 4 & 42 & F & bedside & 7.371 & 45.9 & 77.5 & ND & ND & ND \\
\hline 5 & 42 & $\mathrm{~F}$ & laparotomy & 7.437 & 38.9 & 151 & 7.449 & 38.1 & 90.5 \\
\hline 6 & 67 & M & bedside & 7.433 & 37.4 & 97 & 7.428 & 35.3 & 80.5 \\
\hline 7 & 32 & M & bedside & 7.404 & 45.8 & 100 & 7.441 & 39.7 & 115.7 \\
\hline 8 & 46 & $\mathrm{~F}$ & laparotomy & 7.64 & 27.8 & 133 & 7.416 & 46 & 84.2 \\
\hline 9 & 61 & M & bedside & 7.372 & 49 & 69 & 7.433 & 42.9 & 86.9 \\
\hline 10 & 56 & $\mathrm{~F}$ & bedside & 7.433 & 47 & 75.9 & ND & ND & ND \\
\hline 11 & 59 & M & bedside & 7.405 & 39.6 & 83.8 & 7.458 & 39.4 & 104.7 \\
\hline 12 & 36 & $\mathrm{~F}$ & bedside & 7.42 & 45.4 & 85.4 & 7.474 & 38.7 & 92 \\
\hline 13 & 60 & M & bedside & 7.376 & 46.8 & 72.8 & 7.452 & 45 & 93.7 \\
\hline 14 & 38 & $\mathrm{~F}$ & bedside & 7.305 & 47.6 & 37.4 & ND & ND & ND \\
\hline 15 & 56 & F & bedside & 7.426 & 35.5 & 150 & 7.423 & 38.1 & 111.4 \\
\hline 16 & 63 & $\mathrm{~F}$ & bedside & 7.356 & 37.8 & 108 & 7.413 & 38.7 & 86.9 \\
\hline 17 & 43 & M & bedside & 7.387 & 43.8 & 85.3 & 7.437 & 43.2 & 97 \\
\hline 18 & 34 & M & bedside & 7.38 & 47 & 62.4 & 7.501 & 35.7 & 111 \\
\hline 19 & 47 & $\mathrm{~F}$ & bedside & 7.399 & 46.7 & 66.9 & 7.465 & 42 & 105.1 \\
\hline 20 & 45 & $\mathrm{~F}$ & bedside & 7.383 & 45.7 & 81.4 & 7.444 & 38.5 & 93 \\
\hline 21 & 40 & M & bedside & 7.346 & 48.4 & 87.5 & 7.421 & 44.8 & 101.4 \\
\hline & & & Mean \pm SD & $7.39 \pm 0.07$ & $43.70 \pm 5.50$ & $90.40 \pm 27.72$ & $7.44 \pm 0.02$ & $40.73 \pm 3.46$ & $96.09 \pm 10.33$ \\
\hline
\end{tabular}

Ascites were collected at bedside in 19 or just after laparotomy in 2 cases. ND = Not determined. 


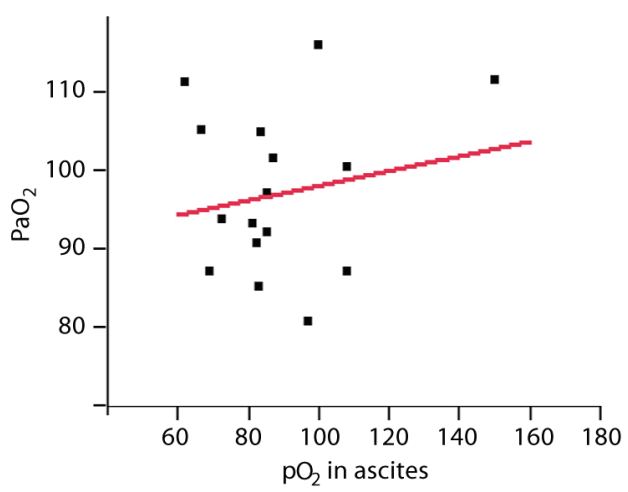

Fig. 1. Arterial blood and ascites were collected at bedside at room temperature in 16 patients and immediately measured with a blood gas analyzer.

\section{References}

1 Sugarbaker PH, Yonemura Y: Clinical pathway for the management of resectable gastric cancer with peritoneal seeding: best palliation with a ray of hope for cure. Oncology 2000;58:96-107.

-2 Tan DS, Agarwal R, Kaye SB: Mechanisms of transcoelomic metastasis in ovarian cancer. Lancet Oncol 2006;7:925-934

3 Liotta LA, Kohn EC: The microenvironment of the tumour-host interface. Nature 2001;411:375-379.

$\checkmark 4$ Fukumura D, Jain RK: Tumor microenvironment abnormalities: causes, consequences, and strategies to normalize. J Cell Biochem 2007;101:937-949.

-5 Ishigami H, Kitayama J, Kaisaki S, Hidemura A, Kato M, Otani K, Kamei T, Soma D, Miyato H, Yamashita H, Nagawa H: Phase II study of weekly intravenous and intraperitoneal paclitaxel combined with s-1 for advanced gastric cancer with peritoneal metastasis. Ann Oncol 2010;21:67-70.

6 Sheckman P, Onderdonk AB, Bartlett JG: Anaerobes in spontaneous peritonitis. Lancet 1977;2:1223.

7 Gitlin N, Stauffer JL, Silvestri RC: The $\mathrm{pH}$ of ascitic fluid in the diagnosis of spontaneous bacterial peritonitis in alcoholic cirrhosis. Hepatology 1982;2:408-411.

8 Simmen HP, Blaser J: Analysis of $\mathrm{pH}$ and $\mathrm{pO}_{2}$ in abscesses, peritoneal fluid, and drainage fluid in the presence or absence of bacterial infection during and after abdominal surgery. Am J Surg 1993;166:24-27.

-9 Noh SM: Measurement of peritoneal fluid $\mathrm{pH}$ in patients with non-serosal invasive gastric cancer. Yonsei Med J 2003;44:45-48.

-10 Senger DR, Van de Water L, Brown LF, Nagy JA, Yeo KT, Yeo TK, Berse B, Jackman RW, Dvorak AM, Dvorak HF: Vascular permeability factor (VPF, VEGF) in tumor biology. Cancer Metastasis Rev 1993;12:303-324.

11 Zebrowski BK, Liu W, Ramirez K, Akagi Y, Mills GB, Ellis LM: Markedly elevated levels of vascular endothelial growth factor in malignant ascites. Ann Surg Oncol 1999;6:373-378.

-12 Kobold S, Hegewisch-Becker S, Oechsle K, Jordan K, Bokemeyer C, Atanackovic D: Intraperitoneal VEGF inhibition using bevacizumab: a potential approach for the symptomatic treatment of malignant ascites? Oncologist 2009;14:1242-1251.

13 Hockel M SK, Aral B, Mitze M, Schaffer U, Vaupel P: Association between tumor hypoxia and malignant progression in advanced cancer of the uterine cervix. Cancer Res 1996;56:4509-4515.

-14 Brizel DM SG, Prosnitz LR, Scher RL, Dewhirst MW: Tumor hypoxia adversely affects the prognosis of carcinoma of the head and neck. Int J Radiat Oncol Biol Phys 1997;38:285-289.

15 Vaupel P KD, Höckel M: Oxygen status of malignant tumors: pathogenesis of hypoxia and significance for tumor therapy. Semin Oncol 2001;28:29-35.

-16 Armstrong DK, Bundy B, Wenzel L, Huang HQ, Baergen R, Lele S, Copeland LJ, Walker JL, Burger RA: Intraperitoneal cisplatin and paclitaxel in ovarian cancer. N Engl J Med 2006;354:34-43.

17 Tennant DA, Duran RV, Gottlieb E: Targeting metabolic transformation for cancer therapy. Nat Rev Cancer 2010;10:267-277. 